\title{
MEMORIA Y LITERATURA: ESCRIBIR DESDE EL EXILIO
}

JAVIER SÁNCHEZ ZAPATERO

UNIVERSIDAD DE SALAMANCA

\section{El EXILIO COMO GENERADOR EXPRESIVO}

El exiliado es una "persona que se ve obligada a salir o a permanecer fuera de su país a raíz de un bien fundado temor a la persecución $-\mathrm{o}$ a la simple imposibilidad de disfrutar de sus derechos individuales - por motivos de raza, credo, nacionalidad o ideas políticas" y que "considera que su exilio es temporal (a pesar de que pueda durar toda la vida), deseando regresar a su patria cuando las condiciones lo permitan - pero incapaz o no dispuesto a hacerlo si persisten los factores que lo mantienen alejado de ella - ". ${ }^{1}$ No sólo está obligado a vivir lejos de su país, sino que además no puede volver mientras persistan las causas que provocaron su marcha. La imposición, directa o indirecta, de la partida y la imposibilidad del retorno se convierten así en las características que diferencian el exilio de cualquier otro tipo de proceso migratorio.

${ }^{1}$ G. Da Cunha-Giabbai, El exilio. Realidad y ficción, Montevideo, Arca, 1992, p. 15. 
Es, pues, alguien a quien se ha despojado de su identidad y de sus raíces, que se convertirán desde el mismo momento de su marcha en obsesivo recuerdo. Por eso la permanencia en el extranjero es considerada, aunque se perpetúe, como eventual y la vuelta a la patria perdida es motivo constante de deseo. Junto a la nostalgia y a las ansias de volver, se ha de destacar como característica común en el pensamiento de los exiliados la sensación de desgarro. Todo exilio implica un cese en la vida que hasta entonces se ha llevado, por lo que supone una alteración esencial de la vida humana que paraliza la existencia hasta hacer de ella una realidad rota, vacía y fantasmal más cercana a la muerte que a la vida. La abrupta salida del país, así como la carencia de ritos protectores como el de la despedida en el momento de partir, hacen que el desasosiego y la intranquilidad llenen su vida, dividida desde la partida entre el deseo de "volver" y el temor de "no volver".

Esta experiencia traumática afecta de manera especial a los escritores, cuya producción literaria, como señaló Esteban Salazar Chapela, periodista y escritor instalado en Londres después de la Guerra Civil Española, se ve alterada por el paso por el exilio:

Hay una literatura de destierro, no ya sólo porque esta literatura esté escrita fuera, sino porque lleva en sí algo que sólo el destierro puede dar: un desdoblamiento de la visión del escritor producido por el mismo tajo que ha sufrido su vida, un continuo zigzag mental y sentimental de cabeza y de corazón, entre su ayer y su hoy. ${ }^{2}$

También Francisco Ayala expresó su convencimiento en la necesidad de tener en cuenta la fractura en el desarrollo de la personalidad que produce la marcha del país y la estancia en el exilio a la hora de valorar la obra de los autores exiliados, señalando su influencia en el momento de gestación:

El literato produce a partir de su personal genio; pero este impulso propio requiere ser realizado sobre la base de unos materiales de experiencia con los que se relacionará no sólo el contenido concreto de su obra, y no sólo el grado de su logro estético, sino incluso la posibilidad misma - posibilidad espiritual, tanto como material - de ejecutarla. (...) Distinto al nuestro [al de los autores exiliados] es el caso normal del escritor que por particular decisión se expatría, toma distancia, corre mundo, vive aparte y luego, al volver, se encuentra con que han mudado las cosas $y$, enseguida, al

\footnotetext{
${ }^{2}$ E. Salazar Chapela, «Homenaje a José Moreno Villa», Caracola, s/n (1956), p. 19.
} 
reflexionar sobre sí mismo, descubre que él también ha sufrido entre tanto mutaciones (...). No hay en esto anomalía ni daño. ${ }^{3}$

La cita de Ayala hace referencia a los autores que, por su propia voluntad y sin perder por ello la posibilidad de regresar cuando deseen a su patria de origen, deciden vivir la experiencia del "autoexilio". Samuel Beckett, Vicente Huidobro, Alejo Carpentier, Juan Goytisolo o James Joyce (que hizo de la necesidad de huir del opresivo entorno habitual para lograr la plena realización el tema de su novela Retrato del artista adolescente) son algunos de los escritores que, buscando la inspiración creativa o la liberación de los orígenes para intentar trascender los modos literarios nacionales, abandonaron su país. La asfixia socio-política y la imposibilidad de alcanzar un desarrollo pleno en un ambiente opresor suelen estar en la base del "autoexilio". La posibilidad de elección de los que optan por esta marcha voluntaria marca la diferencia con los que se ven obligados a abandonar su país.

Es el exiliado un ser que no sólo se ve obligado a vivir fuera de su espacio natural contra su voluntad, sino que es además arrancado sin remedio de su tiempo. En palabras del escritor polaco exiliado Joseph Wittlin, "al sentirse alienado de la vida en el presente, la vida anterior se hace más intensa y tiraniza su vida interior". ${ }^{4}$ El pasado se convierte así en su único punto de referencia, mitificado y deseado a través del recuerdo y transformado en constante objeto de comparación con todo lo que encuentra en su país de acogida. El tiempo presente queda anulado por completo al permanecer entre la vida anterior mitificada y la vida futura, representada por la ilusión de volver al país de origen, ilusión tanto más idealizada cuanto mayor sea la imposibilidad de realizarla. El recuerdo de la patria abandonada enlaza, por tanto, el presente, el pasado y el futuro del exiliado.

Así, la abundancia de textos que, dentro del corpus de obras de los escritores obligados a abandonar forzosamente su patria, se dedican a recrear el pasado del autor y de su país de origen ha de explicarse por los sentimientos de nostalgia que invaden al exiliado en la tierra en la que se ha refugiado. Siente allí la necesidad de recuperar la sociedad a la que antes pertenecía, no sólo porque en su situación echa en falta la adherencia a un proyecto colectivo, sino porque la memoria es la única forma que tiene de seguir

\footnotetext{
${ }^{3}$ F. Ayala, El escritor en la sociedad de masas, Buenos Aires, Sur, 1958, pp. 22-23.

${ }^{4}$ Vid. P. Tabori, Anatomy of Exile, Londres, Harrap, 1972, p. 17.
} 
vinculado a ella. Los recuerdos históricos y autobiográficos se integran en los textos transformados en metáforas e imágenes que se rescatan del olvido y se aderezan con la realidad de la experiencia migratoria. El recuerdo del país abandonado intenta convertirse así en el mejor antídoto contra el desarraigo.

La nostalgia y la vuelta al pasado del autor desterrado se cristalizan en el tratamiento literario de una serie de temas, entre los que el recuerdo de la niñez ocupa un lugar destacado, tal y como ha señalado José Ramón Marra-López:

El tiempo de mayor inocencia e ilusión, de alegre esperanza humana, estremecida ante el fabuloso descubrimiento del mundo, el tiempo que más se presta a la lírica idealización del narrador es su infancia. En ella está contenida la mayor parte de los recuerdos más puros y entrañables: la tierra que le vio nacer, los padres, el primer amor, las innumerables imágenes que no se olvidan y que permanecen grabadas en nuestra alma o que resurgen, inexorables y dolorosas, ante la apasionada nostalgia, ante el obstinado y obsesionante recuerdo del desterrado. Es el idealismo total y absoluto, lleno de encanto maravilloso, en donde el escritor vuelca su corazón sonriendo, en medio de tanta tristeza agobiante, olvidándose de todo. ${ }^{5}$

Volver a la infancia no sólo supone regresar literariamente a la patria que tanto se ansía, sino también dar un paso más hacia la reconstitución de la identidad del sujeto, bruscamente dañada tras el trauma del exilio. Durante la niñez, cuando aún no se han interiorizado los valores simbólicos, se producen los primeros descubrimientos perceptivos, con lo que ciertos elementos cobran una dimensión unívoca que hace que con el tiempo se conviertan en mitos personales a los que recurrir en el futuro. La recreación histórica puede centrarse también en el pasado inmediato. Recuperar los momentos previos a la salida del país ayuda a los desterrados a encontrar los motivos causantes de su situación y poder trascender así el sufrimiento que ésta provoca. En el exilio republicano español, por ejemplo, son múltiples los ejemplos de autores que escriben, basándose fundamentalmente en sus recuerdos, sobre la Guerra Civil Española: Mercé Rododera (La plaza del Diamante), Paulino Masip (El diario de Hamlet García), Ramón J. Sender (El rey y la reina), Ernesto Salazar Chapela (En aquella Valencia), Arturo Barea (La llama), José Ramón Arana (El cura de Almuniaced), Max Aub (El laberinto mágico), etc.

Aunque el pasado es el tiempo en el que de forma constante vive todo exiliado a través del recuerdo, la novedad de encontrarse en un ambiente

${ }^{5}$ J. R. Marra-López, Narrativa española fuera de España, Madrid, Guadarrama, 1963, p. 9. 
diferente al habitual y la carga emocional que implica su particular condición vital pueden estimular también al escritor. No ha sido ésta, sin embargo, materia especialmente fecunda para los autores desterrados, que, al sentir que su presencia en la sociedad que les acogía era transitoria, pocas veces se sintieron arraigados a ella, lo que explica que su literatura apenas se beneficiara del contacto con nuevos ambientes culturales. De hecho, el propio recuerdo del país dejado está en muchas ocasiones en el germen de las obras que recrean la cotidianeidad de los territorios de acogida, centradas en la comparación de las sociedades de origen y de destino. Esta obsesión por el pasado en la patria abandonado tiene una doble cara, expresada en el opuesto dialéctico de la memoria: el olvido. El miedo a no recordar, y también a no ser recordado, marca el periplo vital de los exiliados, convirtiendo en necesidad el dejar testimonio de su vida pasada.

Paradójicamente, la nostalgia se convierte al mismo tiempo en alivio del dolor, ya que no es sino una aproximación vital a la tierra ansiada y una constante esperanza de vuelta, y en impedimento para que los exiliados consigan adaptarse a la sociedad que les acoge. El lugar de llegada no es tan importante como el de partida en el exilio, que siempre es un viaje "desde", nunca "hacia". El permanente recuerdo del país abandonado provoca la mitificación de éste, ya que la patria es "la imagen de todos los bienes", dejando de "corresponder a una realidad geográfica determinada para convertirse en una especie de paraíso terrenal".${ }^{6}$ En semejantes circunstancias, es lógico que se convierta en tarea difícil la aclimatación al nuevo país, que siempre parecerá peor que el abandonado. Además, hay que tener en cuenta que la adaptación puede hacer pensar a los exiliados que el regreso está más lejano. Encontrar un sitio en la nueva sociedad puede suponer acabar con la identidad (más bien, con la falta de identidad) que lleva consigo el exilio y romper así los lazos con todo el pasado.

A pesar de ello, es evidente que son muchos los que consiguen integrarse plenamente en el país que les acoge, olvidando en ocasiones de forma voluntaria y consciente su patria natal. La situación a la que éstos llegan ha sido denominada por Claudio Guillén como "contraexilio", ya que en ellos la experiencia del abandono de la patria no produce sensaciones de desarraigo y soledad, sino de solidaridad universal:

\footnotetext{
${ }^{6}$ V. Llorens, Literatura, historia y política, Madrid, Ediciones de la Revista de Occidente, 1967, p. 26.
} 
El ser humano (...) conforme se muda de lugar y de sociedad, se encuentra en condiciones de descubrir o de comprender más profundamente todo cuanto tiene en común con los demás hombres, uniéndose a ellos más allá de las fronteras de lo local y de lo particular.?

Jorge Semprún ha insistido en la necesidad de trascender las barreras espaciales como única solución para sobrevivir al exilio. Si se considera al mundo entero como la única y verdadera patria, difícilmente podrá el exilio hacer mella en quien lo sufre, como señaló el autor para referirse a su propia experiencia: « Yo nunca podría volver a ninguna patria. Ya no habría patria para mí. Y no la habría nunca. O habría muchas, lo que en el fondo sería lo mismo.» ${ }^{8}$

La sublimación de la sociedad perdida afecta tanto al plano geográfico como al cronológico. Desde el exilio no sólo se sueña con la tierra dejada, sino también con un tiempo irrecuperable que se identifica con el inmediatamente anterior a los sucesos, a menudo convulsos, que produjeron la marcha del país de origen. La salida suele justificarse por la implicación en algún tipo de ideología o de forma política concreta, cuya defensa desde el extranjero va a ser asumida como proyecto vital. Uno de los exilios en los que de forma más clara se observa esta característica es el producido tras la Guerra Civil Española: hasta la consolidación de la democracia en nuestro país permanecieron vigentes las instituciones republicanas expatriadas. La asunción como proyecto vital de la defensa de las ideologías o regímenes políticos cobra en ocasiones un sentido redentor, al aliviar el sentimiento de culpa que pueden experimentar los exiliados al recordar a los compañeros caídos en los conflictos bélicos anteriores a su marcha o a aquellos que no pudieron huir. La mitificación de la sociedad dejada convierte en tarea imposible la consecución de la plenitud con la vuelta, pues el exiliado que regresa no sólo busca un lugar geográfico, sino también una época y una forma de vida que, debido al inevitable paso del tiempo (y a que la sociedad a menudo ha sido ordenada en su ausencia con unos parámetros contrarios a los defendidos por él), ya no existe. El recuerdo del país termina por convertirse en un sustrato cultural abstracto que, formado por una serie de imágenes evocadoras y creencias, basa su consistencia en la lengua y en la ideología. En las páginas finales de La gallina ciega, el diario que Max Aub escribió tras su viaje por España en 1969, después de treinta años de exilio, se puede leer: «Regresé y me voy. En ningún momento tuve la

${ }^{7}$ C. Guillén, El sol de los desterrados: literatura y exilio, Barcelona, Quaderns Crema, 1995, p. 22.

${ }^{8}$ J. Semprún, La escritura o la vida, Barcelona, Tusquets, 1997, p. 125. 
sensación de formar parte de este nuevo país que ha usurpado su lugar al que estuvo aquí antes, no que le haya heredado.»"

La implicación con el pasado no es, sin embargo, exclusiva de aquellos que se vieron obligados a salir del país. El denominado "exilio interior", fenómeno también de alcance universal, agrupa a todas aquellas personas que, sin necesidad de abandonar su patria, se convierten en exiliados, añorando la vida pasada y viéndose obligados a soportar un régimen que no comparten y en el que no se les permite expresarse libremente. Como indicó el escritor uruguayo Mario Benedetti al referirse a sus compatriotas durante su periodo de exilio: «Todos estuvimos amputados: ellos, de la libertad; nosotros del contexto.» ${ }^{10}$

La obsesión por la vuelta se convierte en motor de la vida del exiliado, quien vincula todas sus esperanzas vitales a la posibilidad de volver a pisar el suelo del país que un día se vio obligado a abandonar. A pesar de que el regreso es el objetivo de toda vida en el exilio, la huella de éste en todo aquel que lo sufre provoca la imposibilidad de renunciar a él. La salida del país implica un punto crucial en la vida de cualquier persona, de forma que es imposible retomar aquello que se dejó en el momento de marchar. La honda marca dejada provoca la conversión en "exiliado perpetuo" de todos aquellos obligados a dejar su patria por causas ajenas a su voluntad, tal y como señaló Adolfo Sánchez Vázquez:

El exiliado descubre con estupor primero, con dolor después, con cierta ironía más tarde, en el momento mismo en que objetivamente ha terminado su exilio, que el tiempo no ha pasado impunemente, y que tanto si vuelve como si no vuelve, jamás dejará de ser un exiliado. ${ }^{11}$

Esta sensación de "exilio sin fin" se observa en numerosas obras literarias que han tratado el tema de la vuelta a casa de los expatriados. El "desexilio", término creado por Benedetti para referirse al trauma del regreso, es, por tanto, una experiencia tan dura como la del exilio. El reencuentro produce un choque entre los recuerdos sublimados en el extranjero y la verdadera imagen del país que inevitablemente lleva al desencanto y a la frustración. La dureza de esta situación se acrecienta si se tiene en cuenta que todo exiliado piensa que su estancia en el extranjero es eventual y que el regreso le devolverá al

\footnotetext{
${ }^{9}$ M. Aub, La gallina ciega , Barcelona, Alba, 2003, p. 116.

${ }^{10}$ M. Benedetti, Articulario: desexilio y perplejidades. Reflexiones desde el sur, Madrid, El País, 1994, p. 16.

${ }^{11}$ P. Carvajal y J. Martín, El exilio español (1936-1978), Barcelona, Planeta, 2002, p. 20.
} 
mismo punto en que abandonó su vida antes de marchar. El individuo que vuelve siempre intenta encontrar aquello que dejó en su partida, sin aceptar que el tiempo que él ha pasado en el extranjero también ha discurrido en su patria natal, que ha cambiado sin que lo haya hecho, evidentemente, la imagen mental que se tenía de ella. A pesar de que las referencias que poseen del país son siempre pasadas, en ocasiones los autores intentan relatar, a través de recuerdos de otros tiempos y de las informaciones indirectas que les van llegando, el presente de su patria, logrando efectuar así, a través de la imaginación, el regreso que tanto ansían. Dentro de estas obras tienen un papel destacado aquellas cuyo tema es la vuelta del exiliado. El regreso está representado en novelas como Andamios, de Mario Benedetti, Las ruinas de la muralla, de Jesús Izcaray, La ciudad de la fortuna, de Elie Wiesel, Señas de identidad, de Juan Goytisolo o La raíz rota, de Arturo Barea. La desubicación y el extrañamiento son características básicas de sus personajes protagonistas, incapaces de asimilar que la patria a la que ellos ansiaban regresar desde el exilio no es más que una imagen mental caduca que poco tiene que ver con el espacio en el que se encuentran al volver. De ahí que no sólo haya que hablar de destierro, sino también de destiempo. Francisco Ayala, que pasó prácticamente toda la dictadura franquista en el exilio americano, expresó así esa situación:

Yo jamás me hice ilusiones de que el exilio fuera una situación transitoria, jamás. Estaba persuadido de que era un punto terminal y [que luego vendría] otra vida, la que fuera, cada cual según sus posibilidades y talento, pero otra vida distinta. En cambio, otra gente, lo cual siempre me parecía lamentable, estaba soñando con la vuelta a un país que ya no existía. Era un sueño verdaderamente increíble. ${ }^{12}$

La experiencia del exilio provoca, pues, un traumatismo en la vida de quien lo sufre que ni siquiera el regreso es capaz de solventar. Esa condición irrenunciable ha sido expresada a través de expresiones como "exiliado perpetuo" o "muerte en vida", frecuentemente utilizadas por aquellos que hubieron de expatriarse.

\footnotetext{
${ }^{12}$ Vid. P. Carvajal y J. Martín, op. cit., p. 32.
} 


\section{LA FUNCIÓN POLÍTICA Y CATÁRTICA DEL EXILIO}

Dentro de la amplia nómina de individuos que han padecido la experiencia del exilio el número de escritores es elevado. Los casos de Ovidio, Séneca, Dante, Voltaire, Víctor Hugo, Unamuno, Brecht o Gelman representan tan sólo algunos ejemplos ilustrativos que ponen de manifiesto la vehemencia con la que el fenómeno ha sido sufrido por los hombres de letras. La indisoluble vinculación que para muchos intelectuales existe entre ética y estética provoca la adquisición de compromisos humanos, sociales y políticos que, en épocas de intolerancia y pensamiento único, pueden llevar al exilio.

La progresiva consolidación de una esfera de debate público en las sociedades occidentales a partir del siglo XVIII, motivada por la gestación de una masa lectora burguesa, provocó que los escritores adquiriesen una función social en la sociedad y que sus opiniones formaran parte del espacio público. La producción literaria pasó a configurar así, tanto por lo dicho como por lo callado, el posicionamiento de sus creadores ante la realidad social. La palabra del intelectual comenzó a ser temida por el poder, al convertirse en una potencial amenaza para él. De hecho, durante el siglo XIX los casos de escritores obligados a abandonar su patria son múltiples, poniendo con ello de manifiesto la conversión de su figura pública en "conciencia y guía de una sociedad en la que se tambalean las instituciones portadoras de valores" ${ }^{13}$ Los ejemplos de Madame de Staël, que hubo de huir de Francia a principios de siglo por su oposición a la política napoleónica, Aleksandr Sergeevic Pushkin, expulsado de la Rusia zarista por su entusiasmo en la defensa de las ideas liberales, los miembros de la Generación de Mayo argentina, obligados a permanecer fuera del país durante la dictadura de Rosas, o el Duque de Rivas y José María Blanco White, dos de los muchos españoles que sufrieron durante el convulso siglo la experiencia del exilio, así lo ponen de manifiesto.

El compromiso ético del intelectual no sólo perdura en el exilio, sino que llega a convertirse, junto con la esperanza del regreso, en su principal sustento y alivio. Los escritores exiliados asumen como tarea vital la defensa de la memoria histórica de un tiempo condenado al olvido o a la deformación revisionista en los países que hubieron de dejar. Legitiman su discurso en el convencimiento de su superioridad moral, y en ocasiones intelectual, sobre aquellos que les han llevado a abandonar su patria, lo que provoca

\footnotetext{
${ }^{13}$ C. Guillén, op. cit., p. 140.
} 
que su visión se vea en determinadas situaciones salpicada por las mismas interpretaciones perniciosas y maniqueas por las que acusan a la versión "oficial" de la Historia. En cualquier caso, la palabra es el único medio eficaz de que disponen para llevar a cabo esta función, como ha señalado Michael Ugarte: «El exilio es uno de los escasos fenómenos en la historia en el que el lenguaje se considera un instrumento más eficaz para el cambio social.» ${ }^{14}$

La recuperación de la memoria histórica está vinculada de forma intrínseca a la predisposición al testimonio de los autores exiliados. La suma de los relatos de sus experiencias vitales configura una voz común que permite unificar, aunque sea desde el imaginario intelectual, a un colectivo caracterizado por la dispersión desde el momento en que ha de abandonar su país de origen. Antonio Muñoz Molina ha estudiado la formación de esa identidad grupal a partir de testimonios históricos individuales:

[Los escritores exiliados] se empeñan obsesivamente en rememorar el pasado, en reconstruirlo, en dar testimonio de lo que vivieron. (...) La mejor literatura del exilio es un gran empeño de recapitulación, una tentativa de comprensión del desastre, y en ella con frecuencia la memoria histórica personal desemboca en los sobresaltos del tiempo histórico, de modo que lo privado y lo público se confunden en un solo relato. ${ }^{15}$

Las vidas de los desterrados parecen concebidas para ser contadas, no sólo por la posibilidad de mostrar a través de la propia experiencia la versión histórica que se considera verdadera y de comprometerse con una cosmovisión identificada con un tiempo pasado al que se vuelve a través de la memoria, sino también por la necesidad de descubrir la verdadera esencia del sujeto creador. En el exilio, el ser humano se encuentra en su estado más puro, sin el manto protector de su comunidad, por lo que necesita afirmar su personalidad a través de la palabra. La confesión sobre su propio ser es el único medio existente para dotar de sentido a una experiencia que, además de truncar expectativas vitales, provoca el aislamiento total del hombre de sus asideros sociales y afectivos. Según Angelina Muñiz-Huberman, el testimonio adquiere una función catártica en la medida en que permite afianzarse al individuo en absoluta soledad y sólo con la esencia de su ser, lo que explicaría la proliferación de textos autobiográficos entre los escritores exiliados:

\footnotetext{
${ }^{14}$ M. Ugarte, Literatura española en el exilio. Un estudio comparativo, Madrid, Siglo XX, 1999, p. 20.

${ }^{15}$ A. Muñoz Molina, «Nubes atravesadas por aviones: la novela fantasma de Paulino Masip», en P. Masip, El diario de Hamlet García, Madrid, Visor Libros-Comunidad de Madrid, 2000, p. 9.
} 
Es la confesión un acto irrepetible, total, absoluto, directo, real, sin adornos. Es la escueta verdad y la imposibilidad del arrepentimiento. Es una huida de sí, un vaciamiento, pero es también un deseo de sostén y de apoyo, de aclaración de los hechos, de búsqueda de sentido. Representa la máxima acción que es dado ejecutar con la palabra. (...) Quien se confiesa arranca de una desesperación que anhela ser curada. Quien se ha cansado de sí mismo y vaga perdido por el mundo necesita expresar su huida para conjurarla y al mismo tiempo para dejar constancia. ${ }^{16}$

La traumática experiencia del exilio provoca la consciente adquisición en quien lo sufre de una nueva identidad. El hecho de que el alejamiento forzoso del país de origen sea concebido como el final abrupto de un ciclo vital, como si de una "muerte en vida" se tratase, motiva la concepción de la existencia anterior como todo un completo y, consecuentemente, la creación de una nueva identidad que puede mirar desde un prisma diferente, el que constituyen la distancia y el cambio, a la antigua. Por eso la confesión ocupa un lugar destacado entre las obras de los exiliados, porque todo testimonio de una vida implica, más que una mimética reproducción de unos acontecimientos históricos, la formación de una nueva identidad del sujeto creador a través de múltiples identidades anteriores. Marra-López expresó así el difícil equilibrio que los autores obligados a vivir fuera de su patria han de mantener entre el recuerdo y la esperanza a la hora de enfrentarse al género confesional:

Las memorias se redactan al final de una vida, clausurada ya la acción, como final de acto, antes de que caiga el telón. Esta es otra ambigüedad del emigrado. Durante muchos años no hace más que escribir memorias, recuerdos, pero sin que la edad y el talante le inviten a clausurar su posible acción futura, pues lógicamente se considera perteneciente a esta tierra y en activo todavía. Mientras, al revés de Segismundo, hace del sueño vida que le apuntale y proporcione la fuerza suficiente para continuar esperando, esa espera que es jugo nutricio indispensable en su existencia. ${ }^{17}$

La importancia de la creación literaria en el exilio como elemento catártico y de lucha política acentúa los problemas que a aquellos que han de vivir forzosamente en un país de asilo se les pueden plantear por desconocer su lengua.

\footnotetext{
${ }^{16}$ A. Muñiz-Huberman, «María Zambrano y el concepto de exilio», en M. Aznar Soler (ed.), Las literaturas del exilio republicano de 1939. Actas del II Congreso Internacional, Bellatera, Associació d'Idees-GEXEL, 1999, p. 106.

${ }^{17}$ J. R. Marra-López, op. cit., p. 100.
} 
La sensación de soledad y abandono consustancial hace que los desterrados se aferren con fuerza a su propio idioma, uno de los pocos bienes que aún no han perdido. Aunque la extrañeza del idioma de la patria de acogida es perceptible por todos los exiliados, son los escritores los que más sufren la imposibilidad de comunicarse de forma satisfactoria con quienes les rodean. Vicente Llorens analizó, dentro de su extensa bibliografía sobre el exilio, la angustia del problema del idioma, motivada en muchos desterrados por el temor a deteriorar su lengua de origen o incluso por considerar la adaptación lingüística un paso más en la aclimatación en el país de acogida y, por tanto, una barrera al ansiado regreso:

Esta muerte muda, en que el habla se extingue por falta de su natural aliento, ¿a quién puede afectar más sensiblemente que al poeta, cuya razón de vida parece inseparable de la lengua? Se comprende que tema como nadie su pérdida y se esfuerce por mantenerla viva de algún modo bajo la dolorosa sensación de vacío que experimenta al no oírla más a su alrededor. ${ }^{18}$

Se entienden así reacciones como las de Ovidio, quien, desde su exilio en las costas del mar Negro, se lamentaba de no poder entenderse con los getas y sármatas con los que tenía que convivir, el Duque de Rivas, que recitaba en voz alta pasajes de obras españolas en su exilio londinense o Pedro Salinas, que acogió con extrema alegría la posibilidad de trasladarse durante un tiempo de su exilio estadounidense a Puerto Rico y reestablecer así el contacto con el mundo de habla hispánica. La reacción del poeta de la Generación del 27 demuestra la validez de la teoría de José Gaos sobre los "transterrados" (los exiliados españoles que se instalaron en países se habla hispana) ${ }^{19}$ y pone de manifiesto que la identidad de valores culturales y lingüísticos entre el país de origen y el de acogida influyen en el modo de vivir la experiencia del exilio.

Las situaciones de bilingüismo que pueden producirse después de los forzosos cambios de residencia pueden desarrollarse, grosso modo, de cuatro formas diferentes. Se puede ignorar por completo el idioma del país de acogida, o mantener la lengua natal sin por ello dejar de aprender la del lugar de asilo, como hacen la gran mayoría de exiliados, desarrollando lo que Claudio Guillén

\footnotetext{
${ }^{18}$ V. Llorens, op. cit., p. 36.

${ }^{19}$ Según Gaos, "transterrados son aquellos que han sufrido un cambio geográfico dentro de su mismo territorio, queriéndose con él aludir a la situación espiritual de los exiliados españoles en los países hispanoamericanos, donde, aunque hayan sufrido una traslación geográfica, se hallan instalados dentro de una cultura que mantiene los mismos valores espirituales y lingüísticos" (vid. J. L. Abellán, El exilio como constante y como categoría, Madrid, Biblioteca Nueva, 2001, p. 79).
} 
ha denominado "bilingüismo latente" ${ }^{20}$ Las otras dos opciones contemplan la utilización del idioma aprendido en la tierra en la que el exiliado se ve obligado a permanecer. Así, Joseph Conrad, polaco de nacimiento, ${ }^{21}$ creó toda su obra en su lengua de adopción, el inglés. Otros autores, en cambio, como José María Blanco White, Vladimir Nabokov, Jorge Semprún o Milan Kundera han de ser considerados escritores bilingües, pues parte de su producción literaria está compuesta en el idioma del país en el se exiliaron.

Incluso en los casos en los que no se produce trauma lingüístico alguno, la separación del país de origen conlleva el alejamiento del panorama cultural al que hasta entonces se pertenecía. Los autores exiliados no pueden ser incluidos en ningún canon, pues permanecen en el exilio precisamente por su rechazo a los valores sociales y políticos que sustentan la norma impuesta por la cultura dominante. La suya es una contracultura que sólo con el tiempo puede llegar a adquirir legitimidad..$^{22} \mathrm{Al}$ perder el contacto con el marco de referencia intelectual y artístico en el que hasta entonces habían circulado sus libros, el exiliado pone fin al diálogo con el que había sido su público. Las obras de los desterrados rara vez llegan a sus países de origen (y si lo hacen, suelen ser mutiladas por el filtro de la censura o distribuidas de forma clandestina), pues sería una contradicción que los mismos poderes que han instigado su salida del país consintieran la entrada de sus textos. Este aislamiento cultural es especialmente perceptible en los casos en los que el exilio se produce por motivos políticos. Al vincular la identidad nacional a un proyecto ideológico, se considera que todo aquel que mantenga una postura crítica con el pensamiento dominante es enemigo del país. De hecho, expresiones como "antinacionales" o "enemigos de la patria" son constantes en la retórica de los defensores de regímenes totalitarios y excluyentes.

\footnotetext{
20 "El bilingüismo latente como fruto de la estancia en un país extranjero es condición propia de la persona culta y viajera, obligada por su vocación literaria a efectuar un tajo en su ser interior cuando escribe y quizás, en el fondo, a simplificarse" (vid. C. Guillén, Entre lo uno y lo diverso, Barcelona, Crítica, 1985, p. 328).

${ }^{21}$ Berdichev, la localidad natal de Conrad, pertenece actualmente a Ucrania.

${ }^{22}$ Tal legitimación no ha de caer nunca en la mitificación. Como han denunciado autores como Santos Sanz Villanueva o Andrés Trapiello, la prohibición que suele pesar sobre las obras de los autores exiliados produce una recepción mitificada que crea confusión entre el público (vid. S. Sanz Villanueva, "La narrativa del exilio», en J. L. Abellán (dir.), El exilio español de 1939. Volumen 4: Cultura y Literatura, Madrid, Taurus, 1977 y A. Trapiello, Las armas y las letras, Planeta, Barcelona, 1994). Más peligrosa que esa mitificación es, sin embargo, la frecuente tendencia a olvidar la herencia del exilio, impidiendo su normal integración en los cánones culturales.
} 
La ruptura de la comunicación entre el autor y sus lectores modifica la naturaleza del acto creativo, ya que, como reconocen los autores de la Escuela de Constanza, fundadores de la Estética de la Recepción, las obras no pueden concebirse sin la participación de aquellos a quienes van dirigidas. El destinatario forma parte de un constructo superior al propio acto de la comunicación literaria, el contexto, que influye de forma determinante en la configuración de las obras. El autor en el exilio desconoce qué tipo de público va a convertirse en receptor de sus textos, lo que puede llevar a convertir el acto de escritura en "una rutina profesional desenvuelta en el vacío y (...), sin engarces con el mundo exterior, una actividad desprovista de sentido". ${ }^{23}$ Aunque la relación entre público y autor exiliado apenas ha merecido hasta ahora la atención de la crítica y la investigación literaria, las reflexiones de los escritores que se vieron condenados a prescindir de su masa lectora habitual por encontrarse fuera de su país parecen coincidir en la idea de que la única salida para que la escritura desde el exilio sea efectiva, o quizá para se considere como tal, es la de obviar la incertidumbre respecto al destinatario. Así lo manifestó Max Aub, que se autodefinía como "un escritor sin público" :24 «¿Para quién escribo? No lo sé, ni creo que ningún escritor bien nacido lo sepa. Para quién le dé la gana. Para quien le guste lo que y como escribo.» ${ }^{25}$

Francisco Ayala se expresó en términos parecidos al reflexionar sobre la cuestión desde su exilio americano: «Si nos preguntamos: ¿para quién escribimos nosotros? Para todos y para nadie, sería la respuesta. Nuestras palabras van al viento: confiemos en que algunas de ellas no se pierdan.» ${ }^{26}$

El contraste entre la libertad con la que pueden expresarse los autores en el destierro y la falta de compatriotas lectores que puedan gozar de ella fue expuesta del siguiente modo por Vladimir Nabokov al referirse a la situación de los escritores liberales que huyeron de Rusia tras la revolución soviética:

El afortunado grupo de expatriados estaba ahora en condiciones de proseguir su labor con tan absoluta impunidad que, de hecho, muchos de ellos se preguntaban a veces a sí mismos si su sensación de estar disfrutando de una completa libertad mental no era consecuencia de que actuaban en un vacío. ${ }^{27}$

\footnotetext{
${ }^{23}$ F. Ayala, op. cit., p. 8.

${ }^{24}$ I. Soldevila Durante, El compromiso de la imaginación. Vida y obra de Max Aub, Segorbe, Fundación Max Aub, 1999, p. 55.

${ }^{25}$ M. Aub, Aforismos en el laberinto, Barcelona, Edhasa, 2003, p. 119.

${ }^{26}$ F. Ayala, op. cit., p. 29.

${ }^{27}$ V. Nabokov, Habla, memoria, Barcelona, Anagrama, 2000, p. 278.
} 
El miedo a ser olvidado en su país de origen por la falta de relación con el que hasta el momento de su marcha había sido su público habitual es superado por los autores a través de la creación artística. Escribir sobre la patria es una forma de acercarse, como también lo es lograr ser difundido en ella. Ser leído en el país del que se ha salido obligado por las circunstancias no sólo implica tener la posibilidad de exponer en él un discurso contrario a la interpretación histórica impuesta desde el poder, sino también seguir vinculado en él y evitar el olvido al que teme todo exiliado. De ahí que la escritura sea una forma de seguir conectado a la patria, como se puede observar en uno de los textos fundacionales de la literatura del exilio, la primera de las elegías ovidianas de Tristes, que está dirigida precisamente al propio texto concebido en el destierro. Ovidio desea que su obra pueda hacer lo que él no puede y tanto ansía: volver a Roma. Ser leído en el país de origen es una forma de seguir vinculado a él, la gran obsesión de toda persona en el exilio, como ponen estos versos de manifiesto: «Ve en mi lugar y contempla Roma, tú que puedes.» ${ }^{28}$

\section{CONCLUSIONES: ESCRIBIR EN EL EXILIO, ESCRIBIR CONTRA EL OLVIDO}

Repetida en innumerables ocasiones desde los orígenes de la humanidad, la experiencia del exilio ha ido generando con el paso de los siglos una serie de respuestas literarias análogas. A pesar de que la omnipresencia y la variedad social e histórica del fenómeno impiden la realización de cualquier sistematización de tipo teórico sobre él, la recurrencia con que se repiten determinados rasgos temáticos y, en menor medida, formales en la producción de aquellos autores forzados por las circunstancias a abandonar sus países obliga a plantearse la universalidad de la literatura del exilio. Como se ha esbozado en este artículo, desde el paradigmático caso de Ovidio, cuya obra en el destierro se convirtió en un modelo de referencia e imitación constante, en prácticamente todos los textos escritos en una situación similar a la del poeta latino al ser confinado en la Tracia subyacen una serie de estructuras que no hacen sino desvelar cómo la universalidad y la omnipresencia histórica del fenómeno tienen su correlato en las reacciones artísticas que provoca. De ahí que los tradicionales marcos epistemológicos sincrónicos y nacionales se antojen insuficientes para llevar a cabo el estudio de una literatura de alcance multisecular e intercultural cuyas características se repiten de forma recurrente

\footnotetext{
${ }^{28}$ Ovidio, Tristes. Pónticas, Madrid, Gredos, 1992, p. 79.
} 
en la obra de autores tan dispares y tan distantes en el tiempo como Séneca, Chü Yüan, Dante, Stäel, Mann, Benedetti o Salinas. Para estos autores, las repercusiones del exilio presentan una naturaleza dual, pues además de afectar al desarrollo de su propia existencia modifican los parámetros de su creación. Sus obras no podrían entenderse en su totalidad, por tanto, sin tener en cuenta la experiencia histórica personal que condiciona su gestación, dotada, tal y como se ha señalado, de alcance intercultural.

A pesar de que tradicionalmente se ha vinculado de forma casi exclusiva la literatura de los autores exiliados con los modelos elegíacos basados en el lamento por la tierra perdida, las obras de muchos de los escritores forzados a abandonar su tierra logran trascender el mero sentimiento de desamparo. La capacidad para trascender el sufrimiento y convertir su producción en testimonio moral de denuncia y crítica de dimensiones universales demuestra el carácter transgresor que en ocasiones puede tener la literatura compuesta en el exilio, cuyas producciones suponen una respuesta a la interpretación histórica llevada a cabo desde el poder.

Desde el exilio, los autores conciben su creación como un continuo mirar hacia su patria y su pasado (porque todo destierro implica también un "destiempo") para recomponer su desarrollo reciente y otorgar voz y presencia histórica a través de la escritura al colectivo exiliado, para el que todo es sistemáticamente negado. La creación literaria es el único modo a través del que los autores pueden seguir sintiéndose partícipes de un proyecto colectivo nacional. Alejados de su país, la escritura es el único modo que les queda de seguir en él. Es la suya, por tanto, una lucha contra el olvido, tanto en su vertiente pasiva (ser olvidado por sus compatriotas al ser expulsado) como activa (olvidar el país que hubo de dejar).

La indeleble huella que el exilio deja en quien lo sufre, manifestada literariamente, como se ha venido explicando, en el tratamiento de una serie de temáticas relacionadas con la idea de la pérdida y en la intención de construir un testimonio a favor de la memoria histórica que pueda luchar contra el olvido, demuestra la conveniencia de afrontar el estudio de los autores forzados a abandonar y permanecer fuera de sus países desde un marco analítico común que incida en la análogas condiciones desde que las que componen sus obras. El estudio comparativo de la rica tradición cultural conformada por estos escritores a lo largo de la historia ha de ser, por tanto, uno de los retos que la crítica literaria se proponga afrontar los años venideros. 


\section{BibLIOGRAFÍA}

Abellán, J. L. , El exilio como constante y como categoría, Biblioteca Nueva, Madrid, 2001.

Aub, M., Aforismos en el laberinto, Barcelona, Edhasa [edición y notas de Javier Quiñones], 2003.

---------, La gallina ciega, Barcelona, Alba [edición y notas de Manuel Aznar Soler], 2003.

Ayala, F., El escritor en la sociedad de masas, Buenos Aires, Sur, 1958.

Benedetti, M., Articulario: desexilio y perplejidades. Reflexiones desde el sur, Madrid, El País, 1994.

Carvajal, P. y J. Martín, El exilio español (1936-1978), Barcelona, Planeta, 2002.

Da Cunha-Giabbai, G., El exilio. Realidad y ficción, Montevideo, Arca, 1992.

Guillén, C., El sol de los desterrados: literatura y exilio, Barcelona, Quaderns Cremà, 1995.

, Entre lo uno y lo diverso, Barcelona, Crítica, 1985.

Llorens, V., Literatura, historia y política, Madrid, Ediciones de la Revista de Occidente, 1967.

Marra-López, J. R., Narrativa española fuera de España, Madrid, Guadarrama, 1963

Muñiz-Huberman, A., «María Zambrano y el concepto de exilio», en M. Aznar Soler (ed.), Las literaturas del exilio republicano de 1939. Actas del II Congreso Internacional, Bellatera, Associació d'Idees-GEXEL, 1999, pp. 103-121.

Muñoz MolinA, A., «Nubes atravesadas por aviones: la novela fantasma de Paulino Masip», prólogo a P. Masip, El diario de Hamlet García, Madrid, Visor LibrosComunidad de Madrid, 2000, pp. 7-12.

Nавокоv, V., Habla, memoria, Anagrama, Barcelona, 2000.

Ovidio, Tristes. Pónticas, Madrid, Gredos [traducción, edición y notas de de José González Vázquez], 1992.

Salazar Chapela, E., «Hom enaje a José Moreno Viшa», en Caracola, s/n (1956), pp. 14-22.

Sanz Vil lanueva, S., "La narrativa del exilio”, en J. L. Abellán (dir.), El exilio español de 1939. Volumen 4: Cultura y Literatura, Madrid, Taurus, 1977.

SEMPrún, J., La escritura o la vida, Barcelona, Tusquets, 1997.

Soldevila Durante, I., El compromiso de la imaginación. Vida y obra de Max Aub, Segorbe, Fundación Max Aub, 1999.

TABORI, P., Anatomy of Exile, Londres, Harrap, 1972.

Trapiello, A., Las armas y las letras, Barcelona, Planeta, 1994.

Ugarte, M., Literatura española en el exilio. Un estudio comparativo, Madrid, Siglo XX, 1999. 